\title{
Association of hepatitis C virus NS5B variants with resistance to new antiviral drugs among untreated patients
}

\author{
Magda Cristina Bernardino Castilho ${ }^{1 /+}$, Angélica Nascimento Martins ${ }^{2}$, Ingrid Siciliano Horbach ${ }^{2}$, \\ Renata de Mello Perez ${ }^{3}$, Fatima Aparecida Ferreira Figueiredo ${ }^{3}$, Paulo de Tarso Aparecida Pinto ${ }^{4}$, \\ Leticia Cancela Nabuco ${ }^{4}$, Dirce Bonfim de Lima ${ }^{5}$, Amílcar Tanuri², \\ Luis Cristóvão Porto1, Orlando da Costa Ferreira Júnior ${ }^{1,2}$
}

\author{
'Laboratório de Histocompatibilidade e Criopreservação, Policlínica Piquet Carneiro, Departamento de Histologia e Embriologia \\ ${ }^{3}$ Serviço de Gastroenterologia ${ }^{5}$ Serviço de Doenças Infecciosas e Parasitárias, Hospital Universitário Pedro Ernesto, \\ Universidade do Estado do Rio de Janeiro, Rio de Janeiro, RJ, Brasil ${ }^{2}$ Laboratório de Virologia Molecular, \\ Centro de Ciências da Saúde, Departamento de Genética, Universidade Federal do Rio de Janeiro, Rio de Janeiro, RJ, Brasil \\ ${ }^{4}$ Serviço de Gastroenterologia, Hospital Federal dos Servidores do Estado, Rio de Janeiro, RJ, Brasil
}

Mutations located in the 109-amino acid fragment of NS5B are typically associated with resistance to interferon (IFN) and ribavirin (RIB) and to new antiviral drugs. The prevalence of these mutations was examined in 69 drug-naïve individuals with hepatitis C virus (HCV) infections in Rio de Janeiro, Brazil. Mutations related to nonresponse to IFN/RIB were observed in all subtypes studied ( $1 a, 1 b, 2 b, 3 a$ and 4$)$. The most common mutation was Q309R, present in all subtypes, except subtype $2 b$ with frequency above $20 \%$. D244N was detected only in subtype $3 a$ and A333E was detected only in subtype 2b. We did not detect the S282T, S326G or T329I mutations in any of the samples analysed. Of note, the C316N mutation, previously related to a new non-nucleoside compound (HCV796 and AG-021541), was observed in only eight of 33 (24\%) samples from subtype 1b. Site 316 was under positive selection in this $H C V$ variant. Our data highlight the presence of previously described resistance mutations in HCV genotypes from drug-naïve patients.

Key words: HCV - NS5B - genotyping - Brazilian sequences - resistance mutation

The hepatitis $\mathrm{C}$ virus (HCV) infection is estimated to be globally prevalent at $2.2 \%$, corresponding to approximately 170 million $\mathrm{HCV}$-positive individuals, most of whom are chronically infected (Global Burden of Hepatitis C Working Group 2004). In Brazil, prevalence of HCV-negative individuals has only been estimated in blood donors and varies from $0.3 \%$ in the state of Santa Catarina, in the South region, to $5.9 \%$ in the state of Amazonas, in the North Region (Rosini et al. 2003, da Fonseca \& Brasil 2004).

$\mathrm{HCV}$ belongs to the Flaviviridae family and the virally encoded polypeptide precursor is co and posttranslationally processed by host and viral proteases into at least 10 distinct products (C, E1, E2, P7, NS2, NS3, NS4A, NS4B, NS5A and NS5B). The structural proteins core (C) and envelope (E1 and E2) are the major components of the viral particle. The nonstructural proteins (P7, NS2 to NS5B) are required for viral genome replication (Qin et al. 2001, Luca et al. 2009).

$\mathrm{HCV}$ is currently divided into six genotypes and new variants are classified either as new genotypes or as subtypes depending on the genetic distance from previously described viruses (Simmonds et al. 1994, 2005, Robertson et al. 1998, Kuiken \& Simmonds 2009). The distri-

\footnotetext{
Financial support: HLA and Cryopreservation Lab/UERJ + Corresponding author:magdacastilho@yahoo.com.br Received 21 March 2011

Accepted 8 September 2011
}

bution of HCV genotypes varies in different regions of the world. Throughout all regions of Brazil, genotype 1 is the most frequently detected, followed by genotypes 3 and 2 (Campiotto et al. 2005).

Although there are many new antiviral agents being tested to treat $\mathrm{HCV}$ infection, such as nucleoside and nonnucleoside inhibitors and protease inhibitors, HCV treatment is still primarily based on interferon-alfa (INF- $\alpha$ ) and ribavirin (RBV). However, the effectiveness of this combination therapy is primarily determined by the $\mathrm{HCV}$ genotype: in particular, of individuals infected with $\mathrm{HCV}$ genotype 1, only $50 \%$ have shown a sustained virological response (SVR) with INF-RBV therapy. In addition, adherence to pegylated-IFN and RBV treatment is hampered by frequent adverse reactions (Hadziyannis et al. 2004).

IFN has potent antiviral activity but does not act directly on the virus or replication complex. Rather, it acts by inducing IFN-stimulated genes, which establish a non-virus-specific antiviral state within the cell ( $\mathrm{Lu} \&$ Liao 2011). Pawlotsky et al. (2004) reassessed the effects of RBV monotherapy on early viral kinetics and found that RBV led to a small, early and transient reduction in $\mathrm{HCV}$ viraemia in a proportion of patients. When used in combination with IFN, RBV had no effect on the first and second phases of viral kinetics, but did reduce the rebound in viral levels seen before the second dose of IFN. These effects correlated with RBV concentration and elimination half-life. Several mechanisms of RBV action are currently proposed, including (i) immunomodulation, (ii) inhibition of the inosine monophosphate dehydrogenase, (iii) direct inhibition of the HCV-encod- 
ed NS5B RNA polymerase, (iv) induction of lethal viral mutagenesis and (v) modulation of IFN-stimulated gene expression (Hofmann et al. 2008).

Several findings in vitro and in vivo support this explanation for the effects of RBV in hepatitis C. It may be responsible for the second phase viral load decline during IFN-RBV treatment (Herrmann \& Sarrazin 2004, Herrmann \& Zeuzem 2006, Layden-Almer et al. 2006, Martin \& Jensen 2008, Rong \& Perelson 2010). The region of the viral genome that codes for NS5B has been described as an important target in therapy with IFN and RBV (Kukolj et al. 2005, Lu et al. 2007, Lutchman et al. 2007). The mechanisms that lead to viral resistance after IFN/ RBV treatment is still a matter of debate (Horiike et al. 1999, Hadziyannis et al. 2004, Kanda et al. 2004, Asahina et al. 2005, Hamano et al. 2005, Hofmann et al. 2007, 2008, Chung et al. 2008, Kuntzen et al. 2008, Kwong et al. 2008, Nakamura et al. 2008, Cannon et al. 2009, Gaudieri et al. 2009, Rydberg et al. 2009). For instance, Nelson et al. (1995) showed that the mutations that occur in the HCV gene that codes for NS5B did not correlate with response to INF therapy, but Japanese studies associated IFN-RBV failure with mutations in the NS5B gene (Hamano et al. 2005, Hmwe et al. 2010) and Kuntzen et al. (2008) showed that mutations conferred resistance to specifically targeted antiviral therapy drugs in treatmentnaïve patients infected with HCV genotype 1.

Studies involving different viral populations may generate relevant information on primary resistance and molecular signatures that differentiate the major $\mathrm{HCV}$ genotypes. The HCV gene for NS5B codes for the viral RNA-RNA polymerase and many drug-resistance mutations induced by antiviral treatment are located in this region of the genome. In the present study, we targeted the NSB5 catalytic domain in chronically infected, drug-naïve patients living in the state of Rio de Janeiro (RJ), Brazil, and described viral genotypes to show the genetic variability and the genotype's mutations that are typically associated with IFN/RBV combination therapy and new non-nucleoside drugs.

\section{SUBJECTS, MATERIALS AND METHODS}

Samples - Samples were collected from 69 patients with median age of 55 years (range 19-81); 40/69 (58\%) were male. All but two plasma samples came from $\mathrm{HCV}$ chronically infected patients before treatment with IFN/ $\mathrm{RBV}$, in accordance with the medical standard of care in Brazil. One exception was from a patient treated with IFN/RBV for one week (patient 3,403) and the other exception was from a patient on irregular treatment for approximately two years (patient 3,815 ). Informed consent was signed by all individuals upon acceptance into the study and the protocol for the study was approved by two Institutional Ethical Committees (protocol \# 2214-CEP/ HUPE and 000.389-CEP/HSE).

Polymerase chain reaction (PCR) amplification and sequencing of NS5B palm region - Viral RNA was extracted from plasma samples using a QIAamp MiniElute virus spin kit (QIAGEN, Hilden, Germany). cDNA was generated using the high capacity kit (Applied Biosystems). A nested PCR was carried out us- ing specific primers pairs targeting NS5B: two external primers (Fwd 5'CTAGTCATAGCCTCCGTGAA3', Rev 5'GACACCCGCTGTTTTGACTC3') and two internal primers (Fwd 5'ACCCGCTGTTTTGACTCNAC3', Rev 5'CATAGGCTGCGTGAAGGCTC3') corresponding to codons 228-336 (nucleotide position 8283-8611) in accordance with the $\mathrm{H} 77$ reference sequence (GenBank NC_004102.1) (Holland et al. 1996). Briefly, the PCR reaction mixture for the first round consisted of $5 \mu \mathrm{L}$ of cDNA sample, 1X PCR buffer (Invitrogen, USA), $25 \mathrm{mM}$ of each dNTP (Invitrogen, USA), $25 \mathrm{pM}$ of each primer set (Applied Biosystems, USA) and 1.5 U of Taq DNA polymerase (Taq Platinum - Invitrogen, USA) in a final volume of $50 \mu \mathrm{L}$. The PCR cycling condition was also modified from Holland et al. (1996), with an initial denaturation step at $95^{\circ} \mathrm{C}$ for $1 \mathrm{~min}$. The second round used $5 \mu \mathrm{L}$ of primary PCR reaction mixture described above (Holland et al. 1996). The amplicon was visualised by electrophoresis in $1.5 \%$ agarose gel and was then purified using Microcon (UFC7PCR50) according to the manufacturer's recommendations. Both strands of the PCR products were cycle sequenced using the BigDye terminator mix version 3.1 (Applied Biosystems), according to the manufacturer's recommendations, and nucleotide sequences were determined using an automated DNA sequencer ABI 3100.

Sequence analysis - The generated NS5B sequence was compared with all HCV gene sequences available in the GenBank database using the BLAST program (National Centre for Biotechnology Information) and with the Los Alamos Data Base. Alignment of homologous sequences was carried out using DNAstar, BioEdit and CLUSTALW programs, CLUSTALW version 1.8 (Thompson et al. 1997). The primer region was not included in the analysis. Nucleotide and amino acid (aa) mutations were identified in aligned nucleotide and aa sequences using SeqMan and BioEdit. The sequences were determined and submitted in the GenBank database (submitted).

Phylogenetic analysis - NS5B sequences were aligned and edited. Phylogenetic trees were constructed by the neighbour-joining method using the Mega 3.1 program (Kumar et al. 2001). Bootstrap analyses with 1,000 replicates were performed to confirm tree topologies. Evolutionary distance calculations (nucleotide substitution model: Kimura 2-parameter) were also carried out using the MEGA 3.1 program (Kumar et al. 2001).

Calculation of the ratio $d N$ (non-synonymous mutation)/dS (synonymous mutation) - The MEGA 3.1 program was used to calculate values for $d N, d S$ and $d N / d S$ ratios using the Nei-Gojobori method and Jukes-Cantor test.

Resistance profile - Mutations were compared with those described in the literature for this region of the HCV genome with the help of the Los Alamos Database.

\section{RESULTS}

All 69 samples were successfully amplified by the NS5B nested-PCR method described above and were phylogenetically analysed using standard reference specimens. The following distribution of genotypes and subtypes was determined: 24 (35\%) specimens clustered 
with subtype 1a, 33 (48\%) with $1 \mathrm{~b}$, six (8.7\%) with $2 \mathrm{~b}$, four $(5.8 \%)$ with $3 \mathrm{a}$ and two $(2.9 \%)$ with genotype 4 (Fig. 1A). Three isolates $(3,018,3,491$ and 4,302) were clustered between subtypes $1 \mathrm{a}$ and $1 \mathrm{~b}$; therefore, we constructed a separate phylogenetic tree for these samples (Fig. 1B). Based on the phylogenic analysis, we observed that these three samples clustered with subtype $1 b$.

The aa sequences were determined and used to generate an alignment showing all variations against international genotype consensus sequences. The partial sequence of NS5B analysed included the B (codons 282292) and C (codons 317-319) motifs. The sequences of the B motif (SGVLTTSCGNT) were largely stable and all variations found were conservative in nature, representing polymorphisms related to molecular signatures of the different genotypes. The $\mathrm{C}$ motif containing the NS5B catalytic triad GDD sequence was conserved among all samples analysed regardless of genotype. Outside of the $\mathrm{B}$ and $\mathrm{C}$ motif sequences, 72 aa residues out of the 96 aa analysed showed no variation. The 24 variations found were spread along the sequence and were mainly associated with genotype or subtype molecular polymorphisms (Figs 1B, 2).

Although there is large genetic variability among the $\mathrm{HCV}$ genotypes, primary resistance mutations have been described in the literature (Kuntzen et al. 2008). In our samples, we found one mutation $(\mathrm{D} 310 \mathrm{~N})$ that was previously described to be associated with IFN/RBV resistance (Asahina et al. 2005). The substitutions of the D310N mutation were found in all subtypes analysed, except for $1 \mathrm{a}$ and $2 \mathrm{~b}$. D310N was present as a polymorphism prevalent in three samples $(75 \%)$ classified as subtype $3 \mathrm{a}$, in one sample (3\%) classified as subtype $1 \mathrm{~b}$ and in one sample $(50 \%)$ classified as genotype 4 (Fig. 2). Another substitution previously related to IFN/RBV (T329I) was not present in the study dataset (Asahina et al. 2005), but we found three other mutations that were previously related to RBV resistance: D244N, Q309R and A334E (Asahina et al. 2005, Hamano et al. 2005). The D244N mutation was mainly found in subtype 3a as a natural signature of this variant (Asahina et al. 2005). The Q309R mutation was highly prevalent in subtype 1a (13 isolates; $54.1 \%$ ), but was less prevalent in subtype $1 \mathrm{~b}$ (3 isolates; 9\%). Only one isolate from subtype 1a (4.1\%) was found to carry the A333E mutation.

Two other codons (282 and 316) implicated with resistance to new NS5B inhibitors were also within the NS5B fragment sequenced in this study (Dutartre et al. 2006, Shi et al. 2008, McCown et al. 2009). Codon 282 was implicated with mutations related to 2 me-cytosine resistance (mutation S282T) and all isolates analysed coded for serine in this position (Dutartre et al. 2006). The C316N mutation was previously related to a new non-nucleoside compound (HCV796; ViroPharma, Exton, Pennsylvania and Wyeth Research, Philadelphia, Pennsylvania), but eight out of 33 (24\%) patients with subtype $1 \mathrm{~b}$ already carried this primary mutation despite never having been exposed to this new agent (Table I).

Finally, the $d N / d S$ ratios present in the NS5B sequences of different subtypes were very variable. Position 309 seemed to be under strong positive selection $(d \mathrm{~N} / d \mathrm{~S}>1)$ in all subtypes analysed and position 316 was under strong positive selection for subtype $1 \mathrm{~b}(d \mathrm{~N} / d \mathrm{~S}$ ratio $=16)$. Conversely, positions $282,310,326$ and 329 were under strong negative selection pressure $(d \mathrm{~N} / d \mathrm{~S}<1)$. Interestingly, positions 244 and 333, related to mutations implicated in therapy and molecular signatures for HCV genotypes, showed more neutral selection patterns (Table II).

\section{DISCUSSION}

The findings of this study, conducted on 69 samples from $\mathrm{HCV}$ patients, is consistent with the literature showing that subtypes $1 \mathrm{a}, 1 \mathrm{~b}, 2 \mathrm{~b}$ and $3 \mathrm{a}$ are the most common variants found in RJ. Genotype 1 is frequently observed in the southeastern Brazilian population, especially in RJ. Genotypes 2 and 3 are also often observed in this population, but genotypes 4 and 5 are more rare (Campiotto et al. 2005). Therefore, it was interesting to find two samples of genotype 4 in our study population, as it was previously described as a rare genotype in RJ (Oliveira et al. 1999). The sequence fragment analysed in this study encompassed NS5B codons 228-336, including enzyme motifs B and C. Three major domains constitute the structure of the RNA-dependent RNA polymerase, NS5B: fingers, palm and thumb (Ranjith-Kumar \& Kao 2006). The fingers domain is formed by interconnecting loops and the conserved motif $\mathrm{F}$ is inside this domain (Ranjith-Kumar \& Kao 2006). The palm domain is formed by an interconnecting region between the conserved motifs A, B, C, D and E (Ranjith-Kumar \& Kao 2006). Finally, the thumb domain is formed by a $\beta$-loop and the membrane anchor. Motifs A and B are most sensitive to substitutions, whereas mutations of the glycine and the second aspartic acid of the GDD-C motif, the hallmark of most polymerases, are somewhat tolerated and still produce an enzymatically active NS5B protein (Lohmann et al. 2000). This contrasts with the mutation of the conserved catalytic residue D335 which results in an inactive protein (Lohmann et al. 2000). In this study, we focused on the primary sequence of the palm domain because (i) this region has a polymorphism that differentiates major HCV genotypes (Simmonds et al. 1993), (ii) there are reports in the literature showing that resistance mutations to IFN/RBV therapy are located at this domain and (iii) some mutations associated with new antiviral agents are also located at this domain. Many authors have reported NS5B mutations following failure of IFN/RBV treatment and during disease progression (Horiike et al. 1999, Asahina et al. 2005, Hamano et al. 2005, Lutchman et al. 2007).

The most frequent mutation observed in our sample set was Q309R. In contrast, the mutations S282T, S326G and T329I were absent in all HCV subtypes analysed. The genotype-associated mutations detected in this study are in agreement with those reported in the literature. However, our findings highlight the presence of mutations previously associated with antiretroviral therapy in genotype 1 as well in non-genotype 1, although the clinical significance is poorly understood at this moment.

Indeed, this is the case of the $\mathrm{C} 316 \mathrm{~N}$ mutation, which was mainly found in subtype $1 \mathrm{~b}$ and has been associated with a 10 -fold increase in EC50\% to a new experimental 
A

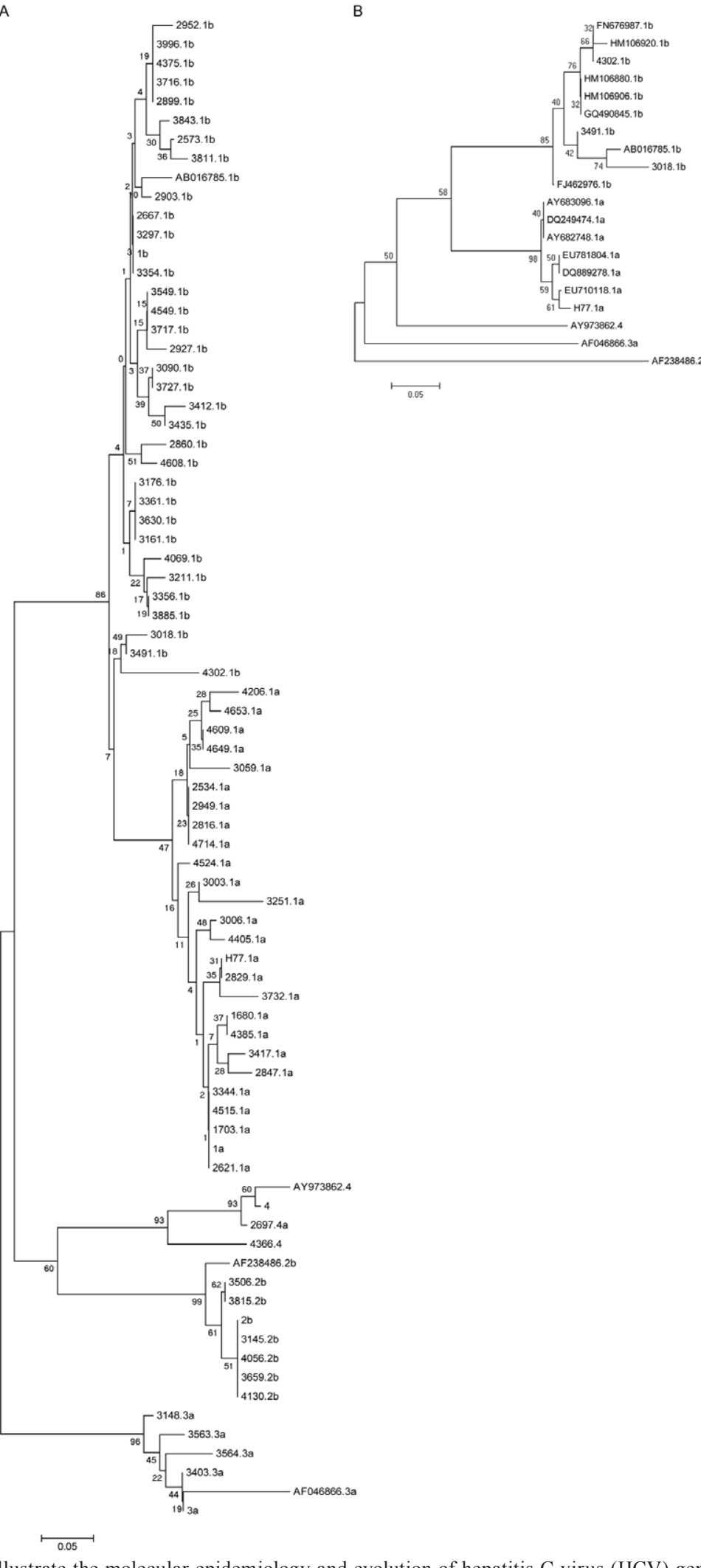

Fig. 1: phylogenetic tree to illustrate the molecular epidemiology and evolution of hepatitis C virus (HCV) genotypes constructed under the neighbour-joining method and the phylogeny test was bootstrap with evolutive model Kimura-two-parameter. A: the sequences include 69 pretreatment NS5B sequences obtained from this study, together with corresponding NS5B sequences extracted from $69 \mathrm{HCV}$ genomes. Reference sequences and consensus sequences prevalent in the state of Rio de Janeiro for all genotypes also has been observed. Pre-treatment partial NS5B sequences obtained in this study are labelled with a number followed by the letter; B: phylogenetic analysis of NS5B sequences illustrating the molecular epidemiology and evolution of HCV genotypes. The phylogenetic tree was constructed in Mega 3.1 program using the neighbourjoining method and the phylogeny test was bootstrap with evolutive model Kimura-two-parameter. 


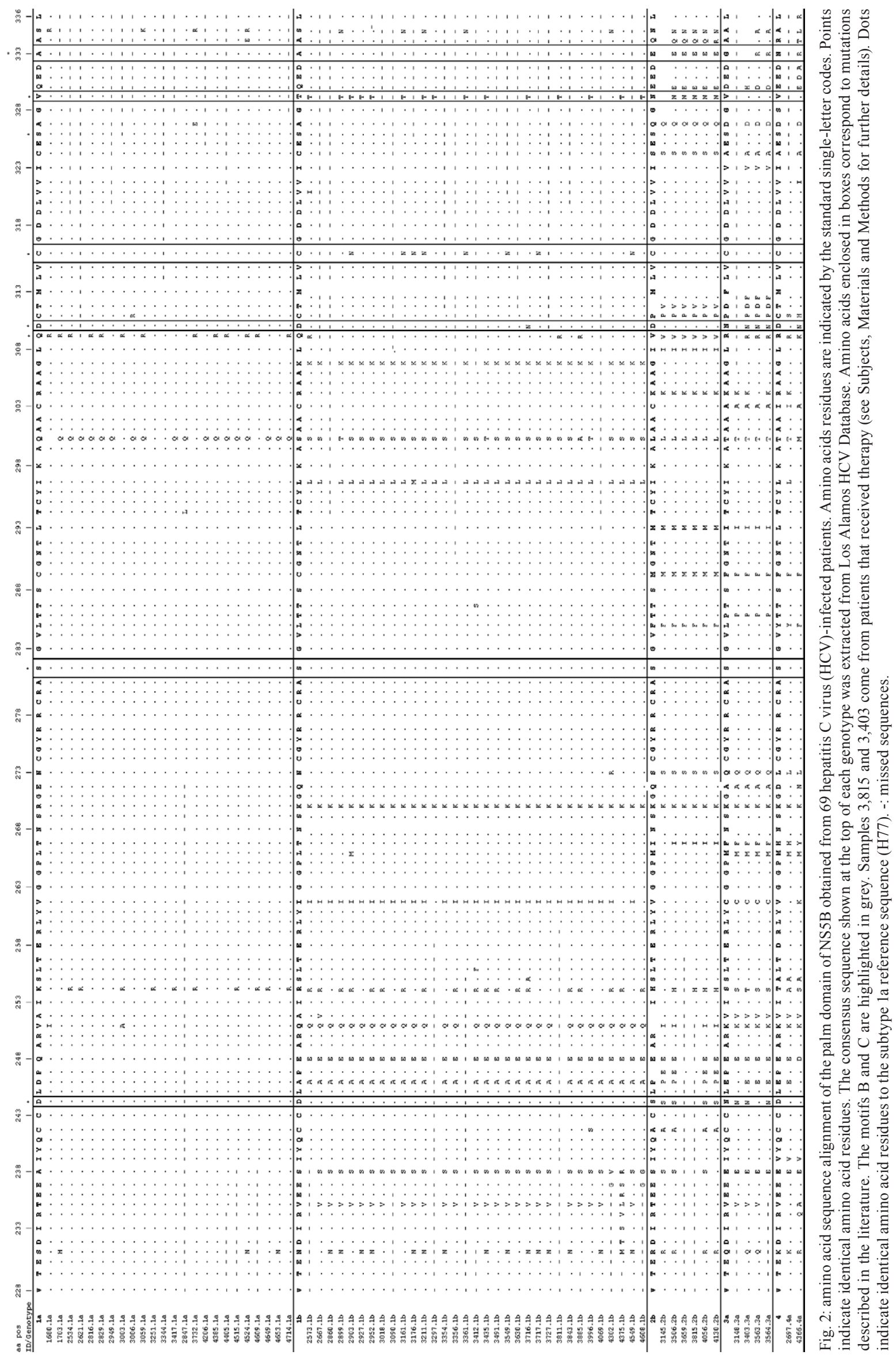


TABLE I

Presence of therapy associated mutations described in literature for hepatitis C virus (HCV) subtypes samples

\begin{tabular}{|c|c|c|c|c|c|c|c|}
\hline \multirow[b]{2}{*}{ Mutations } & \multirow[b]{2}{*}{ References } & \multicolumn{6}{|c|}{ HCV subtypes } \\
\hline & & $\begin{array}{c}1 \mathrm{a} \\
(\mathrm{n}=24) \\
\mathrm{n}(\%)\end{array}$ & $\begin{array}{c}1 \mathrm{~b} \\
(\mathrm{n}=33) \\
\mathrm{n}(\%)\end{array}$ & $\begin{array}{c}2 b \\
(n=6) \\
n(\%)\end{array}$ & $\begin{array}{c}3 a \\
(n=4) \\
n(\%)\end{array}$ & $\begin{array}{c}4 \\
(n=2) \\
n(\%)\end{array}$ & $\begin{array}{c}\text { Total } \\
(\mathrm{n}=69) \\
\mathrm{n}(\%)\end{array}$ \\
\hline $\mathrm{D} 244 \mathrm{~N}^{a}$ & Asahina et al. (2005) & $0(0)$ & $0(0)$ & $0(0)$ & $3(75)$ & $0(0)$ & $3(4.3)$ \\
\hline $\mathrm{S} 282 \mathrm{~T}^{d}$ & Dutartre et al. (2006) & $0(0)$ & $0(0)$ & $0(0)$ & $0(0)$ & $0(0)$ & $0(0)$ \\
\hline $\mathrm{Q}^{309 \mathrm{R}^{a}}$ & Hamano et al. (2005) & $13(54.1)$ & $3(9)$ & $0(0)$ & $3(75)$ & $1(50)$ & $20(29)$ \\
\hline $\mathrm{D} 310 \mathrm{~N}^{c}$ & Asahina et al. (2005) & $0(0)$ & $1(3)$ & $0(0)$ & $3(75)$ & $1(50)$ & $5(7.2)$ \\
\hline $\mathrm{C} 316 \mathrm{~N}^{b}$ & Shi et al. (2008), McCown et al. (2009) & $0(0)$ & $8(24)$ & $0(0)$ & $0(0)$ & $0(0)$ & $8(11.6)$ \\
\hline $\mathrm{S} 326 \mathrm{G}^{a}$ & Asahina et al. (2005) & $0(0)$ & $0(0)$ & $0(0)$ & $0(0)$ & $0(0)$ & $0(0)$ \\
\hline $\mathrm{T}^{2} 29 \mathrm{I}^{c}$ & Asahina et al. (2005) & $0(0)$ & $0(0)$ & $0(0)$ & $0(0)$ & $0(0)$ & $0(0)$ \\
\hline $\mathrm{A} 333 \mathrm{E}^{a}$ & Hamano et al. (2005) & $1(4.1)$ & $0(0)$ & $0(0)$ & $0(0)$ & $0(0)$ & $1(1.4)$ \\
\hline
\end{tabular}

$a$ : ribavirin mutation susceptibility; $b$ : mutation related to non-nucleoside inhibitors Palm II (HCV 796 and AG-021541); $c$ : mutations associated with possible resistance interferon/ribavirin, since it is associated with patients non-responders; $d$ : mutation related to 2 me-cytosine; $\mathrm{n}$ : number of samples.

TABLE II

Positive and negative selection in NS5B codons related to antiviral agents

\begin{tabular}{|c|c|c|c|c|c|c|c|}
\hline $\begin{array}{l}\text { NS5B key } \\
\text { amino } \\
\text { acid position }\end{array}$ & $\begin{array}{l}\text { Number } \\
\text { of samples }\end{array}$ & Subtype & $\begin{array}{l}\text { Codon } \\
\text { change }\end{array}$ & $\begin{array}{l}\text { Amino } \\
\text { acid }\end{array}$ & $d \mathrm{~N}$ & $d \mathrm{~S}$ & $d \mathrm{~N} / d \mathrm{~S}$ \\
\hline \multirow[t]{3}{*}{244} & 1 & $1 b$ & GAC-GAT & D-D & 1 & 4 & 0.25 \\
\hline & $2(\mathrm{Tx}-3403)$ & $3 a$ & AAC-AAT & $\mathrm{N}-\mathrm{N}$ & & & \\
\hline & 1 & $3 a$ & AAC-GAT & N-D & & & \\
\hline 282 & 1 & 4 & AGC-AGT & $\mathrm{S}-\mathrm{S}$ & 0 & 1 & 0 \\
\hline \multirow[t]{5}{*}{309} & 13 & 1a & CAG-CGG & Q-R & 23 & 1 & 23 \\
\hline & 1 & 1a & CAG-CAA & Q-Q & & & \\
\hline & 3 & $1 b$ & CAG-CGG & Q-R & & & \\
\hline & $6(\mathrm{Tx}-3815)$ & $2 b$ & ATG-GTG & $\mathrm{M}-\mathrm{V}$ & & & \\
\hline & 1 & 4 & AGA-AAA & $\mathrm{R}-\mathrm{K}$ & & & \\
\hline \multirow[t]{3}{*}{310} & 1 & $1 b$ & GAT-AAT & D-N & 5 & 0 & 0 \\
\hline & $3(\mathrm{Tx}-3403)$ & $3 a$ & GAC-AAC & $\mathrm{D}-\mathrm{N}$ & & & \\
\hline & 1 & 4 & GAC-AAC & D-N & & & \\
\hline \multirow[t]{2}{*}{316} & 1 & 1a & TGT-TGC & $\mathrm{C}-\mathrm{C}$ & 16 & 1 & 16 \\
\hline & 8 & $1 b$ & TGC-AAC & $\mathrm{C}-\mathrm{N}$ & & & \\
\hline \multirow[t]{2}{*}{326} & 2 & 1a & AGT-AGC & $\mathrm{S}-\mathrm{S}$ & 0 & 4 & 0 \\
\hline & 2 & $1 b$ & AGC-AGT & S-S & & & \\
\hline \multirow[t]{3}{*}{329} & 1 & 1a & GTC-GTA & $\mathrm{V}-\mathrm{V}$ & 0 & 4 & 0 \\
\hline & 2 & $1 b$ & ACC-ACT & $\mathrm{T}-\mathrm{T}$ & & & \\
\hline & 1 & 4 & GTA-GTC & $\mathrm{V}-\mathrm{V}$ & & & \\
\hline \multirow[t]{4}{*}{333} & 2 & 1a & GCG-GCA & A-A & 6 & 11 & 0.545 \\
\hline & 1 & 1a & GCG-GAG & A-E & & & \\
\hline & 3 & $1 b$ & GCG-GCA & A-A & & & \\
\hline & 1 & $2 b$ & CGA-CGG & $\mathrm{R}-\mathrm{R}$ & & & \\
\hline
\end{tabular}

Tx: patient with previous treatment history. 
non-nucleoside drug that binds to NS5B allosteric site 2 . The pre-existence of this mutation at high rates in subtype $1 b$ poses an extra concern in the use of this new agent without a genotypic test before implementing the therapy. It is also interesting to note that position 316 is under high selective pressure in this subtype, as shown by a high $\mathrm{dN} / \mathrm{dS}$ ratio (equal to 16). The high frequency of mutations detected in our study sample is remarkable and suggests that their occurrence is sufficiently spread out, as previously reported (Horiike et al. 1999, Qin et al. 2001, Asahina et al. 2005, Hamano et al. 2005, Dutartre et al. 2006, Lutchman et al. 2007, Kuntzen et al. 2008, McCown et al. 2009, Rydberg et al. 2009). RIB selects for non-synonymous mutations, increasing sensitivity to IFN and leading to SVR status. The main limitation of this work was the short fragment of NS5B analysed (codons 228-236), precluding a detailed examination of resistance mutations associated with new $\mathrm{HCV}$ antiviral drugs. Only a few positions in this analysis $(282,300$ and 316) were linked to resistance to a limited number of non-nucleoside inhibitor compounds (i.e., HCV-769, which has been discontinued and others such as GS9190). In conclusion, little is known about resistance mutations and there are few in vitro studies on HCV. More investigations addressing the impact of the genetic diversity of $\mathrm{HCV}$ should be performed at several locations around the world, including Brazil, for the genotypic characterisation of resistance to old and, perhaps more importantly, to new therapeutic agents.

\section{ACKNOWLEDGEMENTS}

To Juliana Rodrigues Motta, Raphael Pedro Machado Curvo, Carolina Bastos de Sá Borges, Ricardo Cerqueira Alvariz, Karla Gripp Couto de Mello, Patricia Marques da Silva and Hugo Perazzo, for their support.

\section{REFERENCES}

Asahina Y, Izumi N, Enomoto N, Uchihara M, Kurosaki M, Onuki Y, Nishimura Y, Ueda K, Tsuchiya K, Nakanishi H 2005. Mutagenic effects of ribavirin and response to interferon/ribavirin combination therapy in chronic hepatitis C. J Hepatol 43: 623-629.

Campiotto S, Pinho JR, Carrilho FJ, Da Silva LC, Souto FJ, Spinelli V, Pereira LM, Coelho HS, Silva AO, Fonseca JC 2005. Geographic distribution of hepatitis $\mathrm{C}$ virus genotypes in Brazil. Braz J Med Biol Res 38: 41-49.

Cannon NA, Donlin MJ, Mayes LM, Lyra AC, Di Bisceglie AM, Tavis JE 2009. Evidence for action of ribavirin through the hepatitis C virus RNA polymerase. J Viral Hepat 16: 595-604.

Chung RT, Gale M Jr., Polyak SJ, Lemon SM, Liang TJ, Hoofnagle JH 2008. Mechanisms of action of interferon and ribavirin in chronic hepatitis C: summary of a workshop. Hepatology 47: 306-320.

da Fonseca JC, Brasil LM 2004. Hepatitis C virus infection in the Amazon Brazilian region. Rev Soc Bras Med Trop 37: 1-8.

Dutartre H, Bussetta C, Boretto J, Canard B 2006. General catalytic deficiency of hepatitis C virus RNA polymerase with an S282T mutation and mutually exclusive resistance towards 2'-modified nucleotide analogues. Antimicrob Agents Chemother 50: 4161-4169.

Gaudieri S, Rauch A, Pfafferott K, Barnes E, Cheng W, McCaughan G, Shackel N, Jeffrey GP, Mollison L, Baker R 2009. Hepatitis C virus drug resistance and immune-driven adaptations: relevance to new antiviral therapy. Hepatology 49: 1069-1082.
Global Burden of Hepatitis C Working Group 2004. Global burden of disease (GBD) for hepatitis C. J Clin Pharmacol 44: 20-29.

Hadziyannis SJ, Sette H Jr, Morgan TR, Balan V, Diago M, Marcellin P, Ramadori G, Bodenheimer H Jr, Bernstein D, Rizzetto M 2004. Peginterferon-alpha2a and ribavirin combination therapy in chronic hepatitis $\mathrm{C}$ : a randomized study of treatment duration and ribavirin dose. Ann Intern Med 140: 346-355.

Hamano K, Sakamoto N, Enomoto N, Izumi N, Asahina Y, Kurosaki M, Ueda E, Tanabe Y, Maekawa S, Itakura J 2005. Mutations in the NS5B region of the hepatitis C virus genome correlate with clinical outcomes of interferon-alpha plus ribavirin combination therapy. J Gastroenterol Hepatol 20: 1401-1409.

Herrmann E, Sarrazin C 2004. Hepatitis C-virus kinetics and resistance mechanisms. Z Gastroenterol 42: 387-396.

Herrmann E, Zeuzem S 2006. The kinetics of hepatitis C virus. Eur J Gastroenterol Hepatol 18: 339-342.

Hmwe SS, Aizaki H, Date T, Murakami K, Ishii K, Miyamura T, Koike K, Wakita T, Suzuki T 2010. Identification of hepatitis C virus genotype 2 a replicon variants with reduced susceptibility to ribavirin. Antiviral Res 85: 520-524.

Hofmann WP, Herrmann E, Sarrazin C, Zeuzem S 2008. Ribavirin mode of action in chronic hepatitis $\mathrm{C}$ : from clinical use back to molecular mechanisms. Liver Int 28: 1332-1343.

Hofmann WP, Polta A, Herrmann E, Mihm U, Kronenberger B, Sonntag T, Lohmann V, Schonberger B, Zeuzem S, Sarrazin C 2007. Mutagenic effect of ribavirin on hepatitis $C$ nonstructural $5 \mathrm{~B}$ quasispecies in vitro and during antiviral therapy. Gastroenterology 132: 921-930.

Holland PV, Barrera JM, Ercilla MG, Yoshida CF, Wang Y, de Olim GA, Betlach B, Kuramoto K, Okamoto H 1996. Genotyping hepatitis $\mathrm{C}$ virus isolates from Spain, Brazil, China and Macau by a simplified PCR method. J Clin Microbiol 34: 2372-2378.

Horiike N, Michitaka K, Masumoto T, Okura I, Akbar SM, Onji M 1999. Relationship between the effect of interferon therapy and the change of hepatitis $\mathrm{C}$ virus non-structural 5B gene. $J$ Gastroenterol Hepatol 14: 345-351.

Kanda T, Yokosuka O, Imazeki F, Tanaka M, Shino Y, Shimada H, Tomonaga T, Nomura F, Nagao K, Ochiai T, Saisho H 2004. Inhibition of subgenomic hepatitis $\mathrm{C}$ virus RNA in Huh-7 cells: ribavirin induces mutagenesis in HCV RNA. J Viral Hepat 11: 479-487.

Kuiken C, Simmonds P 2009. Nomenclature and numbering of the hepatitis C virus. Methods Mol Biol 510: 33-53.

Kukolj G, McGibbon GA, McKercher G, Marquis M, Lefebvre S, Thauvette L, Gauthier J, Goulet S, Poupart MA, Beaulieu PL 2005. Binding site characterization and resistance to a class of non-nucleoside inhibitors of the hepatitis C virus NS5B polymerase. J Biol Chem 280: 39260-39267.

Kumar S, Tamura K, Jakobsen IB, Nei M 2001. MEGA2: molecular evolutionary genetics analysis software. Bioinformatics 17: 1244-1245.

Kuntzen T, Timm J, Berical A, Lennon N, Berlin AM, Young SK, Lee B, Heckerman D, Carlson J, Reyor LL 2008. Naturally occurring dominant resistance mutations to hepatitis $\mathrm{C}$ virus protease and polymerase inhibitors in treatment-naive patients. Hepatology 48: 1769-1778.

Kwong AD, McNair L, Jacobson I, George S 2008. Recent progress in the development of selected hepatitis C virus NS3.4A protease and NS5B polymerase inhibitors. Curr Opin Pharmacol 8: 522-531.

Layden-Almer JE, Cotler SJ, Layden TJ 2006. Viral kinetics in the treatment of chronic hepatitis C. J Viral Hepat 13: 499-504. 
Lohmann V, Roos A, Korner F, Koch JO, Bartenschlager R 2000. Biochemical and structural analysis of the NS5B RNA-dependent RNA polymerase of the hepatitis C virus. $J$ Viral Hepat 7: 167-174.

Lu L, Dekhtyar T, Masse S, Pithawalla R, Krishnan P, He W, Ng T, Koev G, Stewart K, Larson D 2007. Identification and characterization of mutations conferring resistance to an HCV RNA-dependent RNA polymerase inhibitor in vitro. Antiviral Res 76: 93-97.

Lu MY, Liao F 2011. Interferon-stimulated gene ISG12b2 is localized to the inner mitochondrial membrane and mediates virusinduced cell death. Cell Death Differ 18: 925-936.

Luca C, Grigore L, Vâţă A, Dorobăţ C 2009. Adverse reactions of different treatments in chronic hepatitis C. Rev Med Chir Soc Med Nat Iasi 113: 991-995.

Lutchman G, Danehower S, Song BC, Liang TJ, Hoofnagle JH, Thomson M, Ghany MG 2007. Mutation rate of the hepatitis $\mathrm{C}$ virus NS5B in patients undergoing treatment with ribavirin monotherapy. Gastroenterology 132: 1757-1766.

Martin P, Jensen DM 2008. Ribavirin in the treatment of chronic hepatitis C. J Gastroenterol Hepatol 23: 844-855.

McCown MF, Rajyaguru S, Kular S, Cammack N, Nájera I 2009. GT-1a or GT-1b subtype-specific resistance profiles for hepatitis $\mathrm{C}$ virus inhibitors telaprevir and HCV-796. Antimicrob Agents Chemother 53: 2129-2132.

Nakamura M, Saito H, Ikeda M, Tada S, Kumagai N, Kato N, Shimotohno K, Hibi T 2008. Possible molecular mechanism of the relationship between NS5B polymorphisms and early clearance of hepatitis $\mathrm{C}$ virus during interferon plus ribavirin treatment. J Med Virol 80: 632-639.

Nelson DR, Gray AH, Kolberg JA, Joh J, Urdea MS, Mizokami M, Davis GL, Lau JY 1995. Variations of hepatitis C virus NS5B sequence (nucleotides 8261-8566) do not correlate with response to interferon-alpha therapy. J Viral Hepat 2: 285-292.

Oliveira ML, Bastos FI, Sabino RR, Paetzold U, Schreier E, Pauli G, Yoshida CF 1999. Distribution of HCV genotypes among different exposure categories in Brazil. Braz J Med Biol Res 32: 279-282.

Pawlotsky JM, Dahari H, Neumann AU, Hezode C, Germanidis G, Lonjon I, Castera L, Dhumeaux D 2004. Antiviral action of ribavirin in chronic hepatitis C. Gastroenterology 126: 703-714.

Qin W, Yamashita T, Shirota Y, Lin Y, Wei W, Murakami S 2001. Mutational analysis of the structure and functions of hepatitis $\mathrm{C}$ virus RNA-dependent RNA polymerase. Hepatology 33: 728-737.
Ranjith-Kumar CT, Kao CC 2006. Biochemical activities of the HCV NS5B RNA-dependent RNA polymerase. In SL Tan, Hepatitis $C$ viruses: genomes and molecular biology, Horizon Bioscience, Norfolk, p. 293-310.

Robertson B, Myers G, Howard C, Brettin T, Bukh J, Gaschen B, Gojobori T, Maertens G, Mizokami M, Nainan O 1998. Classification, nomenclature and database development for hepatitis $\mathrm{C}$ virus $(\mathrm{HCV})$ and related viruses: proposals for standardization. International Committee on Virus Taxonomy. Arch Virol 143: 2493-2503.

Rong L, Perelson AS 2010. Treatment of hepatitis C virus infection with interferon and small molecule direct antivirals: viral kinetics and modeling. Crit Rev Immunol 30: 131-148.

Rosini N, Mousse D, Spada C, Treitinger A 2003. Seroprevalence of HbsAg, anti-HBc and anti-HCV in southern Brazil, 1999-2001. Braz J Infect Dis 7: 262-267.

Rydberg EH, Cellucci A, Bartholomew L, Mattu M, Barbato G, Ludmerer SW, Graham DJ, Altamura S, Paonessa G, De Francesco R 2009. Structural basis for resistance of the genotype $2 b$ hepatitis $\mathrm{C}$ virus NS5B polymerase to site A non-nucleoside inhibitors. J Mol Biol 390: 1048-1059.

Shi ST, Herlihy KJ, Graham JP, Fuhrman SA, Doan C, Parge H, Hickey M, Gao J, Yu X, Chau F, Gonzalez J, Li H, Lewis C, Patick AK, Duggal R 2008. In vitro resistance study of AG-021541, a novel non-nucleoside inhibitor of the hepatitis $\mathrm{C}$ virus RNA-dependent RNA polymerase. Antimicrob Agents Chemother 52: 675-683.

Simmonds P, Alberti A, Alter HJ, Bonino F, Bradley DW, Brechot C, Brouwer JT, Chan SW, Chayama K, Chen DS 1994. A proposed system for the nomenclature of hepatitis $\mathrm{C}$ viral genotypes. $\mathrm{He}$ patology 19: 1321-1324.

Simmonds P, Bukh J, Combet C, Deleage G, Enomoto N, Feinstone S, Halfon P, Inchauspe G, Kuiken C, Maertens G 2005. Consensus proposals for a unified system of nomenclature of hepatitis $\mathrm{C}$ virus genotypes. Hepatology 42: 962-973.

Simmonds P, Holmes EC, Cha TA, Chan SW, McOmish F, Irvine B, Beall E, Yap PL, Kolberg J, Urdea MS 1993. Classification of hepatitis $\mathrm{C}$ virus into six major genotypes and a series of subtypes by phylogenetic analysis of the NS-5 region. J Gen Virol 74: 2391-2399.

Thompson JD, Gibson TJ, Plewniak F, Jeanmougin F, Higgins DG 1997. The CLUSTALX windows interface: flexible strategies for multiple sequence alignment aided by quality analysis tools. Nucleic Acids Res 25: 4876-4882. 